\title{
Effect of Irrigation Water Salinity on the Growth of Quinoa Plant Seedlings
}

\author{
Abdullah M. Algosaibi ${ }^{1}$, Mohammed M. El-Garawany ${ }^{2}$, A. E. Badran ${ }^{3} \&$ Abdulrahman M. Almadini $^{1}$ \\ ${ }^{1}$ Agricultural Environment \& Natural Resources Department, College of Agriculture \& Food Sciences, King \\ Faisal University, Saudi Arabia \\ ${ }^{2}$ Agricultral \& Veterinary Research \& Training Station, King Faisal University, Saudi Arabia \\ ${ }^{3}$ Genetic Resources Department, Desert Research Center, Cairo, Egypt \\ Correspondence: A. E. Badran, Genetic Resources Department, Desert Research Center, Cairo, Egypt. E-mail: \\ dr.ayman_badran@yahoo.com
}

Received: April 7, 2015 Accepted: May 21, 2015 Online Published: July 15, 2015

doi:10.5539/jas.v7n8p205 URL: http://dx.doi.org/10.5539/jas.v7n8p205

\begin{abstract}
The experiment aimed to study the effect of the irrigation water quality on the growth of seedlings and its yield of quinoa plant through some traits i.e., plant height, number of leaves per plant, 1000 grains weight, dry weight per plant, stem diameter, inflorescence length and grain yield per plant. Four treatments were used as follow: T1 (low salinity water, EC $1.25 \mathrm{dS} \mathrm{m}^{-1}$ ), T2 (mix water between low salinity water and agricultural drainage water at ratio 1:1, EC $4 \mathrm{dS} \mathrm{m}^{-1}$ ), T3 (agricultural drainage water, EC $8 \mathrm{dS} \mathrm{m}^{-1}$ ) and T4 (high salinity water, EC $16 \mathrm{dS} \mathrm{m}^{-1}$ ). The treatments application was at the beginning of the plant buds so that the amount of irrigation water up to $75 \%$ from field capacity. The significant effects of treatments were found on all tested traits. Also, the results clarified that the rate of chlorophyll ranged between 44.18 (treatment T4) and 53.75 SPAD (treatment T3), water potential of the fourth leaf has ranged from -0.83 to $-1.745 \mathrm{MPa}$ for T1 and T3 treatments, respectively, number of leaves per plant was ranged between 26.5 and 28.5 when the plants were irrigated with $\mathrm{T} 4$ and $\mathrm{T} 1$ irrigation water treatments, respectively. The inflorescence lengths were varied between $8 \mathrm{~cm}$ at T4 treatment and $12 \mathrm{~cm}$ at T2 treatment. The plant height was ranged between $53.5 \mathrm{~cm}$ (T4) and $60.75 \mathrm{~cm}$ (T3). The low values of seed yield were recorded at T4 $(17.05 \mathrm{~g} / \mathrm{plant})$ while the higher values were recorded with T2 treatment $(34.08$ $\mathrm{g}$ /plant). 1000-grain weight values were ranged between $2.97 \mathrm{~g}$ at T2 treatment, and $3.49 \mathrm{~g}$ at treatment $\mathrm{T} 1$.
\end{abstract}

Keywords: quinoa, salinity, field capacity, chlorophyll, seed yield

\section{Introduction}

Salinity and drought are two main environmental factors determining plant productivity and distribution of most major crops (Bartels \& Sunkar, 2005). Soils are classified as saline when the electrical conductivity of a saturated paste (ECe) is $4 \mathrm{dS} \mathrm{m}-1(40 \mathrm{mM} \mathrm{NaCl})$ or more (USDA-ARS, 2008). So, over $6 \%$ of the global land area is affected by salt (Munns, 2005). Salinity inhibits plant growth in two ways: first, it reduces the ability of plants to take up water (osmotic or water-deficit effect); second, excess salt in the transpiration stream causes injury to cells in the transpiring leaves (salt-specific or ion-excess effect) (Greenway \& Munns, 1980). In the same context, Munns and Tester (2008) confirmed that, plants respond to salinity stress in two phases: a rapid response to the increase in external osmotic pressure (starts immediately after the salt concentration around the roots increases to threshold levels, which decrease the new shoot growth) and a slower response due to the accumulation of $\mathrm{Na}^{+}$in leaves (salt accumulation to toxic concentrations and increase senescence of older leaves). Quinoa (Chenopodium quinoa Willd.) has been cultivated in the Andean region for thousands of years, providing highly nutritious food to poor farmers in the Andes (Pearsall, 1992). The conditions for crop growth are very difficult in the high region of the Andes, where the most harmful a biotic adverse factors that affect crop production are drought, frost, soil salinity, hail, snow, wind, flooding, and heat (Garcia et al., 2003). Chenopodium spp. have been cultivated for centuries as a leafy vegetable (Chenopodium album) as well as an important subsidiary grain crop (Chenopodium quinoa and C. album) for human and animal food stuff due to high-protein and essential amino acids (Prakash \& Pal, 1998; Bhargava et al., 2003a), a wide range of vitamins (A, B2, E) and minerals (Ca, Fe, Cu, Mg, Zn) (Repo-Carrasco et al., 2003). Although, quinoa grains do not contain gluten and thus, they cannot be used alone for bread- making. However, they can be mixed with wheat 
flour in the preparation of bread with high nutritional value (Morita et al., 2001). Accordingly, quinoa has been selected by the food and agriculture organization (FAO) as one of the crops destined to offer food security in the $21^{\text {st }}$ century (Jacobsen, 2003). Several studies showed that even halophytes are particularly salt sensitive during the stages of seed germination and seedling establishment (Tobe et al., 2000; Malcolm et al., 2003). However, they have an advantage over plant species that lack strategies to deal with salt in the soil (Tobe et al., 2000; Rosa et al., 2004). Salinity tolerance is a heritable trait with a polygenic character linked to a complex genetic basis that can be used as an efficient criterion for selection of salt resistant populations (Flowers \& Colmer, 2008). There is also evidence to support the view that salt tolerance is a complex physiological trait affecting entirely the plant's life (Flowers, 2004). In addition, the quinoa plant is reported to be tolerant to drought (Garcia et al., 2007), and also resists frost before the flower-bud formation stage (Jacobsen et al., 2005) and salinity (Ruffino et al., 2010; Hariadi et al., 2011). However, the definition of indicators that plant breeders might apply in open field to improve quinoa, for its tolerance or adjustment to saline environments, is still a matter of debate (Razzaghi et al., 2011a).

In the present paper, the aim of this study was to investigate the response of growing quinoa seedling under salinity stress in different growth stages. By measuring the effect of irrigation water quality on some vegetative and physiological parameters and the grain yield, conclusions can be drawn on a promising strategy of salinity water irrigation for the crop.

\section{Materials and Methods}

\subsection{Water Irrigation and Soil Characteristics}

Pots experiment was conducted in a greenhouse of Training and Research Station of Agricultural and Veterinary of King Faisal University, Al-Ahsa. Four treatments used as follow:

1) The first treatment (T1): low salinity well irrigation water treatment (electrical conductivity of irrigation water (ECw), $\left.1.25 \mathrm{dS} \mathrm{m}^{-1}\right)$. 2) The second treatment (T2): mix water between low salinity well irrigation water and agricultural drainage water at ratio $1: 1\left(\mathrm{ECW}, 4 \mathrm{dS} \mathrm{m}^{-1}\right)$. 3) The third treatment (T3): agricultural drainage water (ECw, $8 \mathrm{dS} \mathrm{m}^{-1}$ ). 4) The fourth treatment (T4): high salinity water treatment (ECw, $16 \mathrm{dS} \mathrm{m}^{-1}$ ).

The chemical analysis of treatments water used and in this experiment showed in Table 1.

Table 1. Chemical composition of irrigation water used in treatments

\begin{tabular}{|c|c|c|c|c|c|c|c|c|c|c|}
\hline \multirow{2}{*}{ Treatments } & \multirow{2}{*}{$\mathrm{pH}$} & \multirow{2}{*}{$\mathrm{EC} \mathrm{dSm}^{-1}$} & \multicolumn{4}{|c|}{ Soluble cations meq/L } & \multicolumn{4}{|c|}{ Soluble anions $\mathrm{meq} / \mathrm{L}$} \\
\hline & & & $\mathrm{Na}^{+}$ & $\mathrm{K}^{+}$ & $\mathrm{Ca}^{2+}$ & $\mathrm{Mg}^{2+}$ & $\mathrm{CO}_{3}{ }^{2-}$ & $\mathrm{HCO}_{3}^{-}$ & $\mathrm{Cl}^{-}$ & $\mathrm{SO}_{4}^{2-}$ \\
\hline $\mathrm{T} 1$ & 6.95 & 1.25 & 3.9 & 1.5 & 2.03 & 1.65 & - & 1.31 & 7.10 & 2.23 \\
\hline $\mathrm{T} 2$ & 7.51 & 4.00 & 10.90 & 4.01 & 8.05 & 5.13 & - & 2.58 & 16.13 & 14.02 \\
\hline $\mathrm{T} 3$ & 8.20 & 8.00 & 18.02 & 7.55 & 22.01 & 10.01 & - & 3.25 & 33.12 & 25.32 \\
\hline $\mathrm{T} 4$ & 8.53 & 16.00 & 30.21 & 14.24 & 40.11 & 19.58 & - & 6.89 & 60.58 & 48.12 \\
\hline
\end{tabular}

Note. T1: (EC, $\left.1.25 \mathrm{dS} \mathrm{m}^{-1}\right), \mathrm{T} 2:\left(\mathrm{EC} 4 \mathrm{dS} \mathrm{m}^{-1}\right), \mathrm{T} 3:\left(\mathrm{EC} 8 \mathrm{dS} \mathrm{m}^{-1}\right)$ and T4: (EC $\left.16 \mathrm{dS} \mathrm{m}^{-1}\right)$.

The soil texture is loamy sand and the level of salinity is $2.61 \mathrm{dS} \mathrm{m}^{-1}$ (Table 2). According to that of United States Salinity Laboratory Staff (1954), the soil is suitable for normal plant growth. The $\mathrm{pH}$ value of the soil is 7.62. This is within the optimum range reported by Zucconi and Berttoldi (1978) for optimum plant nutrition, (between 6.5 and 8.50 ). The organic matter of this soil was high (30.2\%). The soil is also characterized by high levels of $\mathrm{N}$ and high levels of $\mathrm{P}$ and $\mathrm{K}$. 
Table 2. Some chemical properties of mixture between soil and compost (1:1) of irrigation water used in treatments

\begin{tabular}{llllll}
\hline Trait & Value & $\begin{array}{l}\text { Trait } \\
{ }^{* *} \text { Soluble ions, } \mathrm{mmol} \mathrm{L}^{-1}\end{array}$ & Value & Trait & Value \\
\hline${ }^{*}$ Sand (\%) & 85.1 & $\mathrm{Ca}^{2+}$ & 5.31 & Total N (\%) & \\
Silt (\%) & 8.5 & $\mathrm{Mg}^{2+}$ & 3.42 & $\mathrm{Av}$. K, ppm & \\
Clay (\%) & 6.4 & $\mathrm{Na}^{+}$ & 2.50 & Av. P, ppm & 16.23 \\
Texture & Loamy sand & $\mathrm{K}^{+}$ & 3.78 & & \\
${ }^{* *} \mathrm{EC}, \mathrm{dSm}^{-1}$ & 2.61 & $\mathrm{CO}_{3}{ }^{2-}$ & 1.6 & & \\
${ }^{* *} \mathrm{pH}$ & 7.62 & $\mathrm{HCO}_{3}{ }^{-}$ & 2.2 & \\
$\mathrm{OM}, \%$ & 30.2 & $\mathrm{SO}_{4}{ }^{2-}$ & 5.2 & & \\
& & $\mathrm{Cl}^{-}$ & 10.9 & & \\
\hline
\end{tabular}

Note. ${ }^{*}$ Mechanical analysis was done by the international pipette methods (Piper, 1957); ${ }^{* *}$ Chemical analyses were performed on saturated paste extract according to procedures outlined by Page et al. (1982).

\subsection{Plant Material and Experimental Design}

Five seeds of C. quinoa willd (Chipaya cv.) were planted in every pot which contained $5 \mathrm{~kg}$ of a mixture of agriculture soil:compost $(1: 1 \mathrm{v}: \mathrm{v})$. The analysis of mixture between soil and compost are showed in Table $1 \mathrm{~b}$. Each treatment consisted of 10 pots. The application of treatments carried out at the beginning of the plant buds stage so that the amount of irrigation water up to $75 \%$ from field capacity. These experiments were set up in a randomized complete block design with four replicates.

\subsection{Measurements of Plant Growth and Yield}

At the end of the experimental period, quinoa plants (Chipaya cv.) were carefully removed from the substrate. Then, the plants of each pot were separately harvested and recorded each of plant height $(\mathrm{cm})$, the total number of leaves per plant, 1000 grains weight $(\mathrm{g})$, dry weight (dried at $740 \mathrm{c}$ for $48 \mathrm{~h})(\mathrm{g} / \mathrm{plant})$, stem diameter $(\mathrm{cm})$, inflorescence length $(\mathrm{cm})$ and grain yield per plant $(\mathrm{g})$ for each treatment. All of the traits measured per ten plants and mean calculated for each trait except some traits calculated in the fourth leaf per ten plants as follows: Amount of chlorophyll was measured using chlorophyll Meter SPAD-502 that is widely used for the rapid, accurate and without causing damage of the amount of chlorophyll present in the leaf. Also, leaf water potential measured in mid-day after covered the targeted leaf (the forth leaf) with a small plastic bag around the leaf to avoids any transpiration. Then quickly placed through the chamber lid which closed tightly. Positive pressure exerted on the leaf inside chamber using nitrogen gas which equals the negative pressure inside the leaf, liquid in the leaf blade will begin to be forced out of the cut edge of the leaf., this pressure value is the leaf water potential (MPa). In the same context, is measured the area of fourth leaf $\left(\mathrm{cm}^{2}\right)$ after measured the amount of chlorophyll.

\subsection{Statistical Analysis}

The data were analyzed statistically by an analysis of variance and the comparison between all the data obtained was made by Duncan's Multiple Range Test (DMRT).

\section{Results}

\subsection{Effect of Salinity on the Vegetative and Physiological Traits}

\subsubsection{The Rate of Chlorophyll in the Fourth Leaf}

Figure 1 illustrates the effect of the quality of irrigation water on the ratio of chlorophyll in the fourth leaf of the quinoa plant, where the results showed that the rate of chlorophyll ranged between $44.18 \mathrm{~T} 4$ treatment (EC $16 \mathrm{dS}$ $\mathrm{m}^{-1}$ ) and $53.75 \%$ of $\mathrm{T} 3$ treatment (EC $8 \mathrm{dS} \mathrm{m}^{-1}$ ) with a standard deviation 3.98 and general average rate $48.33 \%$. Although the effect of irrigation water salinity on plant growth and physiological processes, it is clear that chlorophyll content of quinoa plant seedlings tolerant salinity of irrigation water but decreased with increasing water salinity at $16 \mathrm{dS} \mathrm{m}^{-1}$ (T4). Generally, the results showed that the highest percentage of chlorophyll content in seedling were recorded when exposed to irrigation water with EC $8 \mathrm{dS} \mathrm{m}^{-1}$ (T 3). 


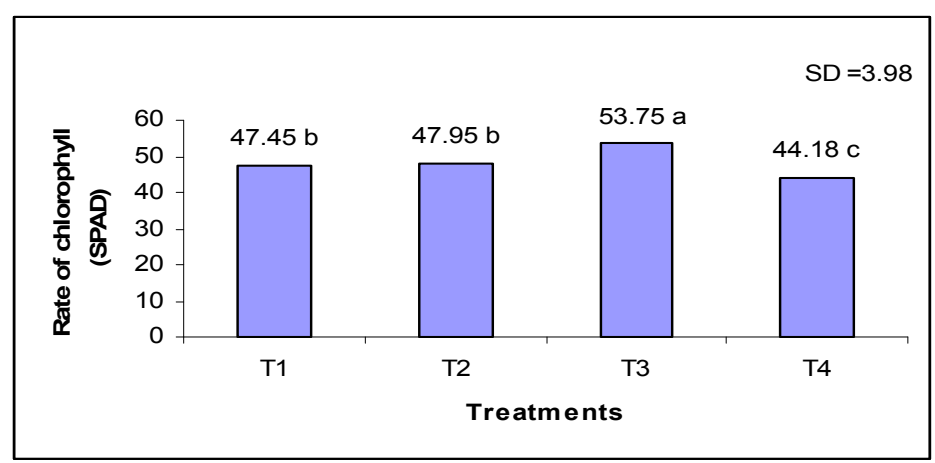

Figure 1. The rate of chlorophyll in the fourth leaf under irrigation salinity water

Note. $\mathrm{SD}=$ Standard deviation, $\mathrm{T} 1:\left(\mathrm{EC}, 1.25 \mathrm{dS} \mathrm{m}^{-1}\right), \mathrm{T} 2:\left(\mathrm{EC} 4 \mathrm{dS} \mathrm{m}^{-1}\right)$, T3: $\left(\mathrm{EC} 8 \mathrm{dS} \mathrm{m}^{-1}\right)$ and T4: (EC $16 \mathrm{dS}$ $\left.\mathrm{m}^{-1}\right)$.

\subsubsection{Water Potential in the Fourth Leaf}

The effect of irrigation water salinity on the water potential in the fourth leaf of quinoa plant seedling, where the results showed that the leaf water potential has ranged from -0.83 to $-1.745 \mathrm{MPa}$ for both $\mathrm{T} 1$ and $\mathrm{T} 3$ treatments respectively, and the general average of leaf water potential -1.14 MPa and the standard deviation 0.53 (Figure 2). These data confirm that the high salinity level of irrigation water reduces the water potential of the leaf which shows the salt osmotic plays a role in the absorption of water. The reason is that salinity may not cause elongation of plant cells but lead to cell division, leading to increased number of cells per unit area, leading to the appearance of dark green, which is reflected in the amount of chlorophyll. So, it must plant that consumes energy for water absorption from the soil solution instead of consumes it for cell growth processes.

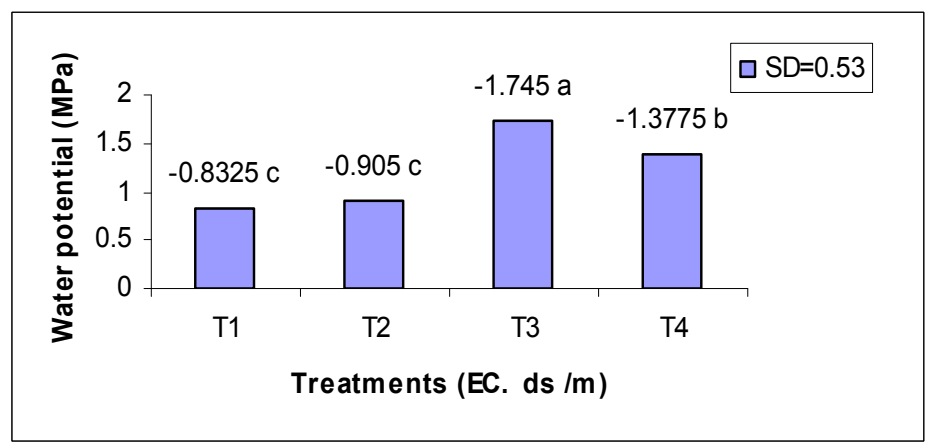

Figure 2. Water potential in the fourth leaf under irrigation salinity water

Note. $\mathrm{SD}=$ Standard deviation, T1: $\left(\mathrm{EC}, 1.25 \mathrm{dS} \mathrm{m}^{-1}\right), \mathrm{T} 2:\left(\mathrm{EC} 4 \mathrm{dS} \mathrm{m}^{-1}\right)$, T3: $\left(\mathrm{EC} 8 \mathrm{dS} \mathrm{m}^{-1}\right)$ and T4: (EC $16 \mathrm{dS}$ $\left.\mathrm{m}^{-1}\right)$.

\subsubsection{The Number of Leaves per Plant}

In Figure 3, the results showed that the number of leaves per plant decreases with increasing salinity of irrigation water from $\mathrm{T} 1\left(\mathrm{EC}, 1.25 \mathrm{dS} \mathrm{m}^{-1}\right)$ to $\mathrm{T} 4\left(\mathrm{EC}, 16 \mathrm{dS} \mathrm{m}^{-1}\right)$, where the values of leaves number per plant per ranged from 26.5 when irrigated using T4 treatment to 28.5 when irrigated using T1 treatment and the general mean of leaves number per plant was recorded 27.08 and the standard deviation was 0.97.Also, the analysis of data explained that, there is no difference between T1 treatment (EC, $1.25 \mathrm{dS} \mathrm{m}^{-1}$ ) and T2 treatment (EC $\left.4 \mathrm{dS} \mathrm{m}^{-1}\right)$ and also there is no difference between T3 (EC $\left.8 \mathrm{dS} \mathrm{m}^{-1}\right)$ and T4 (EC $\left.16 \mathrm{dS} \mathrm{m}^{-1}\right)$. 


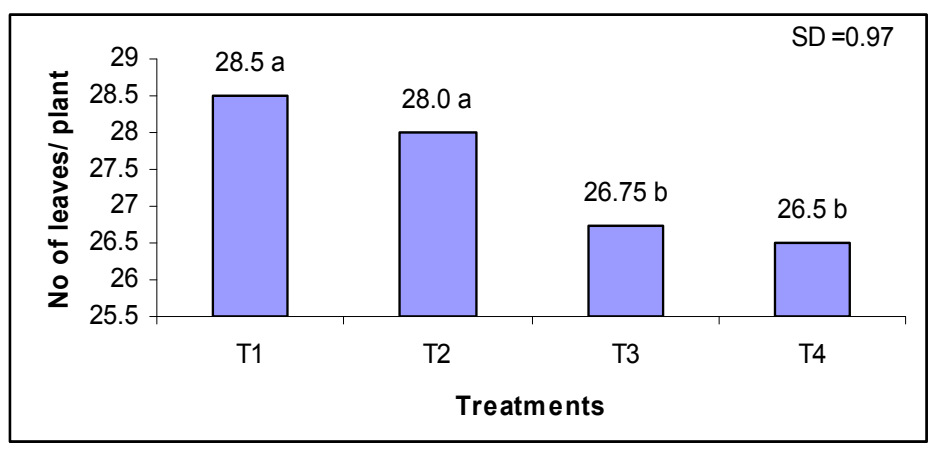

Figure 3. Number of leaves per plant under different irrigation salinity water

Note. $\mathrm{SD}=$ Standard deviation, T1: $\left(\mathrm{EC}, 1.25 \mathrm{dS} \mathrm{m}^{-1}\right), \mathrm{T} 2:\left(\mathrm{EC} 4 \mathrm{dS} \mathrm{m}^{-1}\right)$, T3: $\left(\mathrm{EC} 8 \mathrm{dS} \mathrm{m}^{-1}\right)$ and T4: (EC $16 \mathrm{dS}$ $\left.\mathrm{m}^{-1}\right)$.

\subsubsection{Inflorescence Length}

The length of inflorescence Influenced by the level of salinity irrigation water, as shown in Figures $4 \mathrm{a}$ and $4 \mathrm{~b}$. Where the length ranged between $8 \mathrm{~cm}$ at the level of T4 treatment $\left(\mathrm{EC} 16 \mathrm{dS} \mathrm{m}^{-1}\right)$ and $12 \mathrm{~cm}$ at the level of T2 treatment $\left(\mathrm{EC} 4 \mathrm{dS} \mathrm{m}^{-1}\right)$. The length of the flower of the attributes of good growth and therefore may be affected by salinity of irrigation water. There is no significant in the average length of the flower which exposed to T3 and $\mathrm{T} 4$ treatments and also between $\mathrm{T} 1$ and $\mathrm{T} 3$.

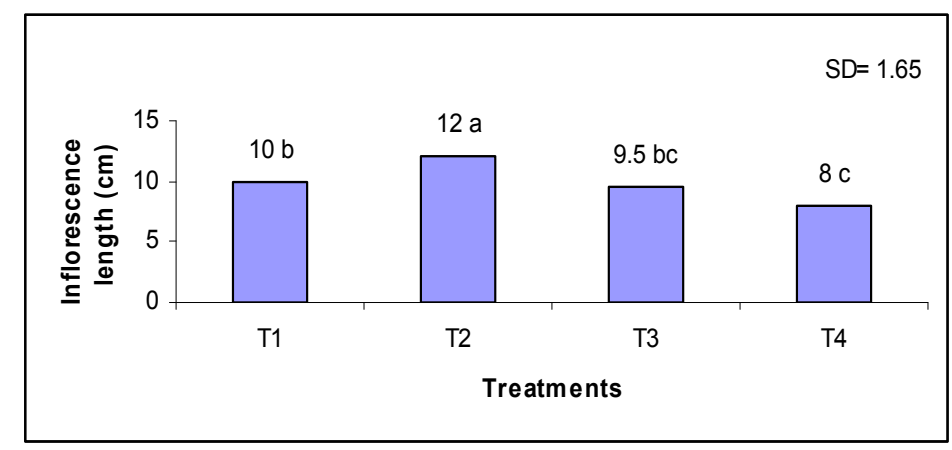

(a)

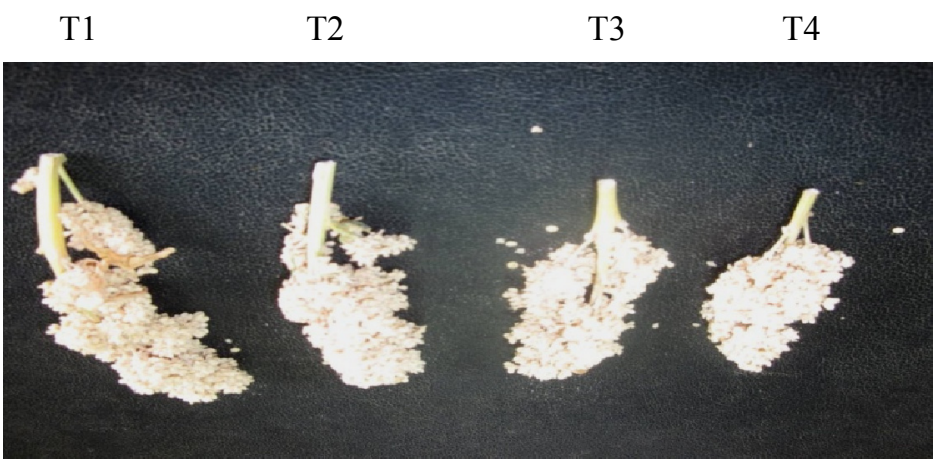

(b)

Figure 4. Inflorescence length under different irrigation salinity water

Note. $\mathrm{SD}=$ Standard deviation, T1: $\left(\mathrm{EC}, 1.25 \mathrm{dS} \mathrm{m}^{-1}\right), \mathrm{T} 2:\left(\mathrm{EC} 4 \mathrm{dS} \mathrm{m}^{-1}\right)$, T3: $\left(\mathrm{EC} 8 \mathrm{dS} \mathrm{m}^{-1}\right)$ and T4: (EC $16 \mathrm{dS}$ $\left.\mathrm{m}^{-1}\right)$. 


\subsubsection{Plant Height}

The results in Figure 5 showed that, the length of the plant after 45 days of agriculture has been influenced by salinity of irrigation water, where the values of plant height ranged between 53.5 to $60.75 \mathrm{~cm}$ when the plants were irrigated using T4 and T3 treatments respectively. In the same manner, There were non-significant differences between treatments $\mathrm{T} 2$ and $\mathrm{T} 4$, where the standard deviation recorded 3.31 and the general average of the plant height recorded $56 \mathrm{~cm}$. Salinity reduces the ability of plants to take up water, and this quickly causes reductions in growth rate, along with a suite of metabolic changes identical to those caused by water stress.

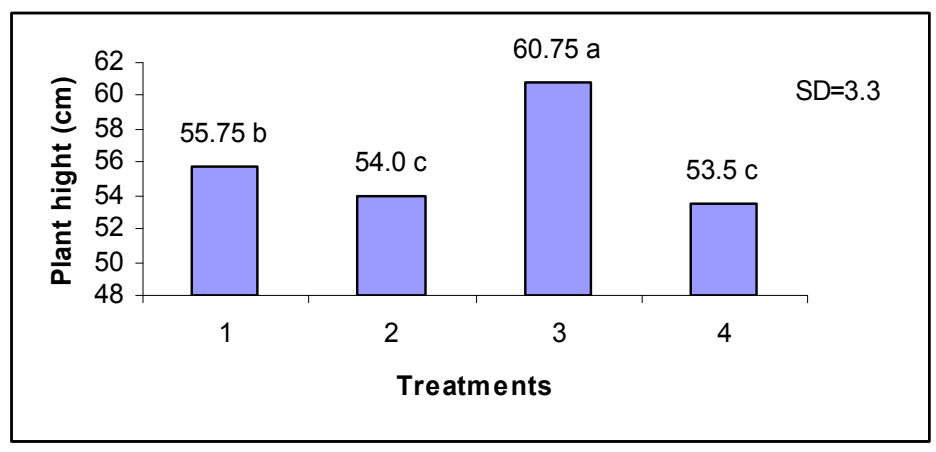

Figure 5. plant height under different irrigation salinity water

Note. $\mathrm{SD}=$ Standard deviation, $\mathrm{T} 1:\left(\mathrm{EC}, 1.25 \mathrm{dS} \mathrm{m}^{-1}\right), \mathrm{T} 2:\left(\mathrm{EC} 4 \mathrm{dS} \mathrm{m}^{-1}\right), \mathrm{T} 3:\left(\mathrm{EC} 8 \mathrm{dS} \mathrm{m}^{-1}\right)$ and T4: (EC $16 \mathrm{dS}$ $\left.\mathrm{m}^{-1}\right)$.

\subsection{Effect of Salinity on Yield and Its Components}

\subsubsection{Grain Yield per Plant and 1000 Grains Weight}

Seed yield per plant ranged between 17.05 using T4 treatment to $34.08 \mathrm{~g}$ using T2 treatment. Where the standard deviation was 7.10 (Figure 6) and the general average of yield was 26.78. According to, the effect of salinity irrigation water on the 1000-grain weight values ranged between $2.97 \mathrm{~g}$ using T2 treatment, and $3.49 \mathrm{~g}$ with T1 treatment. The difference among the averages of the most treatments (T1, T3 and T4) was non-significant, where the ability of the standard deviation recorded 0.31 . The general average value was $3.25 \mathrm{~g}$ (Figure 7).

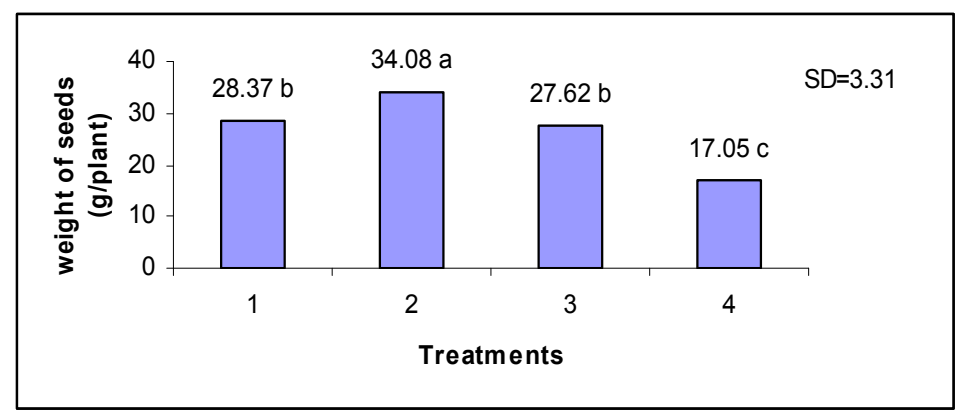

Figure 6 . Weight of seeds/plant under different irrigation salinity water

Note. $\mathrm{SD}=$ Standard deviation, $\mathrm{T} 1:\left(\mathrm{EC}, 1.25 \mathrm{dS} \mathrm{m}^{-1}\right), \mathrm{T} 2:\left(\mathrm{EC} 4 \mathrm{dS} \mathrm{m}^{-1}\right)$, T3: $\left(\mathrm{EC} 8 \mathrm{dS} \mathrm{m}^{-1}\right)$ and T4: (EC $16 \mathrm{dS}$ $\left.\mathrm{m}^{-1}\right)$. 


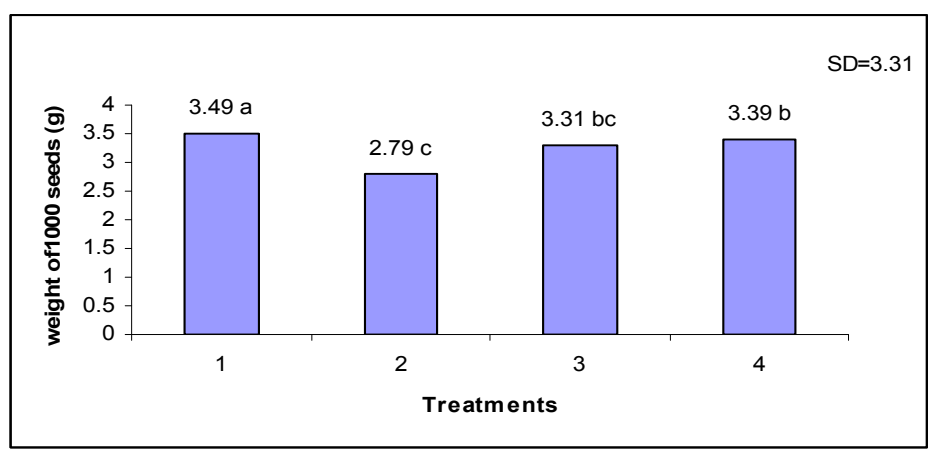

Figure 7. Weight of 1000 seeds under different irrigation salinity water

Note. $\mathrm{SD}=$ Standard deviation, $\mathrm{T} 1:\left(\mathrm{EC}, 1.25 \mathrm{dS} \mathrm{m}^{-1}\right), \mathrm{T} 2:\left(\mathrm{EC} 4 \mathrm{dS} \mathrm{m}^{-1}\right)$, T3: $\left(\mathrm{EC} 8 \mathrm{dS} \mathrm{m}^{-1}\right)$ and T4: (EC $16 \mathrm{dS}$ $\left.\mathrm{m}^{-1}\right)$.

\subsection{Effect of Salinity on Some Traits of Growth}

The results of the influence of irrigation water saline treatments on some traits of growth (no. of days to flowering, no. of days of maturity, leaf area, stem diameter and dry weight/plant) were presented in Table 3 . The results revealed significant differences between irrigation water saline treatments (T1, T2, T3, and T6) with regard the morphological traits studied (number of days to flowering, number of days of maturity, leaf area $\left(\mathrm{cm}^{2}\right)$, stem diameter $(\mathrm{cm})$, dry weight per plant $(\mathrm{g})$. Concerning number of days to flowering, the highest value $(84.59$ days) was obtained at T2 while the lowest value (67.00 days) was obtained under T4 treatment with no significant differences between $\mathrm{T} 1$ and $\mathrm{T} 2$ treatment in their effect on number of days to flowering. The saline treatment $\mathrm{T} 2$ produced the highest no. of maturity days (131.43), whereas the saline treatment T4 produced the least no. of maturity days (95.00). The lowest leaf area was produced by quinoa plants grown under T4 treatments $\left(15.01 \mathrm{~cm}^{2}\right)$ (Table 3). However higher leaf area value $\left(19.00 \mathrm{~cm}^{2}\right)$ was obtained under $\mathrm{T} 2$ treatment as compared to other tested treatments. The dry weight values were ranged from $14.48 \mathrm{~g} / \mathrm{plant}$ (T4) to 19.04 g/plant (T2) (Table 3).

Table 3. The effect of different irrigation treatments on some traits of growth and yield

\begin{tabular}{llllll}
\hline Treatments $^{\$}$ & $\begin{array}{l}\text { No. of days to } \\
\text { flowering }\end{array}$ & $\begin{array}{l}\text { No. of days of } \\
\text { maturity }\end{array}$ & $\begin{array}{l}\text { Leaf area } \\
\left.\mathbf{( c m}^{2}\right)\end{array}$ & $\begin{array}{l}\text { Stem diameter } \\
(\mathbf{c m})\end{array}$ & $\begin{array}{l}\text { Dry weight/plant } \\
(\mathbf{g})\end{array}$ \\
\hline T1 & ${ }^{\$} 75.53 \mathrm{ab}$ & $130.65 \mathrm{a}$ & $18.08 \mathrm{a}$ & $0.81 \mathrm{ab}$ & $17.81 \mathrm{ab}$ \\
$\mathbf{T 2}$ & $84.59 \mathrm{a}$ & $131.43 \mathrm{a}$ & $19.00 \mathrm{a}$ & $0.92 \mathrm{a}$ & $19.04 \mathrm{a}$ \\
$\mathbf{T 3}$ & $71.73 \mathrm{~b}$ & $103.68 \mathrm{~b}$ & $17.02 \mathrm{ab}$ & $0.74 \mathrm{bc}$ & $15.96 \mathrm{bc}$ \\
$\mathbf{T 4}$ & $67.00 \mathrm{~b}$ & $95.00 \mathrm{~b}$ & $15.01 \mathrm{~b}$ & $0.64 \mathrm{c}$ & $14.48 \mathrm{c}$ \\
\hline Average & 74.71 & 115.19 & 17.28 & 0.77 & 16.82 \\
$\mathbf{C V \%}$ & 9.97 & 16.18 & 9.95 & 15.58 & 11.95 \\
$\mathbf{L S D}_{\mathbf{0} .05}$ & 9.66 & 24.16 & 2.23 & 0.16 & 2.61 \\
\hline
\end{tabular}

Note. ${ }^{\$}$ T1: $\left(\mathrm{EC}, 1.25 \mathrm{dS} \mathrm{m}^{-1}\right), \mathrm{T} 2:\left(\mathrm{EC} 4 \mathrm{dS} \mathrm{m}^{-1}\right), \mathrm{T} 3:\left(\mathrm{EC} 8 \mathrm{dS} \mathrm{m}^{-1}\right)$ and T4: (EC $\left.16 \mathrm{dS} \mathrm{m}^{-1}\right)$.

${ }^{\$ \$}$ Any two means not sharing the same letter in common in a column differ significantly at $5 \%$ probability.

\section{Discussion}

\subsection{Effect of Salinity on the Vegetative and Physiological Traits}

The results presented in Figure 1, Tables 3 and 4 are agreement with Ana Maria et al. (2010) who decided that, relative water content, chlorophyll, carotenoids, lipids, and proteins traits in quinoa seedlings were significantly lower under salinity $(250 \mathrm{mM} \mathrm{NaCl})$ and Eisa et al. (2012) who reported that, the net photosynthesis rates of quinoa plant were greatly decreased by high salinity, being $28 \%$ of initial control values at $500 \mathrm{mM} \mathrm{NaCl}$ also they reported that salt-induced growth reduction is presumably due to low photosynthetic supply as a 
consequence of impaired photosynthetic capacity. According to Tammam et al. (2008), Geissler et al. (2009), chlorophyll content in the plant due to the strength of growth as affected by growing conditions, processes of agricultural irrigation and the quality of irrigation water.

About leaf water potential trait, the same trend was earlier reported by Eisa et al. (2012) that confirm that leaf water potential of $C$. quinoa was significantly $(\mathrm{P} \leq 0.05)$ decreased from $-0.6 \mathrm{MPa}$ under control conditions to about $-5 \mathrm{MPa}$ at salinity of $500 \mathrm{mM} \mathrm{NaCl}$. It appears that the effect of salt on morphological and physiological traits of quinoa plan reduce the number of leaves or shoot to provide the energy needed for water absorption is necessary of plant growth. Greeway and Munns (1980) pointed that, the salts inhibit plant growth in two ways, first reduce the plant's ability to absorb water (impact of deficit water) and the second, increase salts in the stream evaporation - transpiration cause damage to the cells in the leaf transpiration (influence qualitative to the salts or the effect of the increase ionic).

In the same context, to discuss the results of inflorescence length (Figures $4 \mathrm{a}$ and $4 \mathrm{~b}$ ) Jacobsen et al. (2001) showed that, quinoa can grow in extreme saline condition up to soil electrical conductivity of $52 \mathrm{dS} \mathrm{m}^{-1}$, with inflorescence size being most sensitive to salinity. Also, the initial reduction in shoot growth is probably due to hormonal signals generated by the roots (Munns, 2002).

\subsection{Effect of Salinity on Yield and Its Components}

Koyro and Eisa (2007) explained that, salt-induced growth reduction is presumably due to low photosynthetic supply as a consequence of impaired photosynthetic capacity. Together, these indicate that C. quinoa is a promising salt-tolerant, in terms of biomass production, and can be grown productively under low to moderate saline condition. Also, they confirmed that all growth traits of quinoa plant affected by the very high salinity where, this effect depends on the type and quantity of salt. In the same manner Cocozza et al. (2013) confirmed that, quinoa plant showed good resistance to water and salt stress through stomatal responses and osmotic adjustments that played a role in the maintenance of a leaf turgor favorable to plant growth and preserved crop yield.

\subsection{Effect of Salinity on Some Traits of Growth}

These results are in agreement with that obtained by Panuccio et al. (2014) in their study on the effect of sea water concentrations $(25,50,75$ and $100 \%)$ on seed germination and early seedling growth of quinoa where they found that the growth parameters (root and shoot length, root morphology, fresh and dry weight, and water content) affected with saline water as comparing with pure water. And they added that all morphological properties decreased with increasing the salinity in water. Also, Koyro et al. (2008) showed that Chenopodium quinoa was able to complete its life cycle and produced seeds even at seawater salinity. However, the growth furthermore, the yield, number of seeds, weight and seed dry matter per plant were significantly reduced in the presence of salinity. The above results in Table 3 revealed that the growth and yield of quinoa plant decrease with increasing salinity irrigation water as a result of the impact on the morphological and physiological characteristics as explained Koyro and Eisa (2007). In the same manner, Bhargava et al. (2003c) showed that, stem diameter, inflorescence/plant and dry weight/plant were determined as factors controlling grain yield on sodic soil. Richards (1992) showed that low external water potential, which result from salt stress, can cause morphological and or functional plant adaptations. Morphological plant adaptations included a reduction in leaf area with a consequent reduction in assimilatory material per unit of plant material and reduction in water use.

\section{Conclusion}

Results clearly revealed that, the increasing of salinity of water over $4 \mathrm{dS} \mathrm{m}^{-1}$ has influence on some traits of growth and yield (no. of days to flowering, no. of days of maturity, leaf area, stem diameter and dry weight/plant), weight of seeds/plant, and inflorescence length. However, the number of leaves per plant decreased with increasing level of salt in irrigation water and water potential in the fourth leaf increased with increasing water salinity. Also, the rate of chlorophyll in the fourth leaf increased with increasing water salt up to T3 (EC 8 $\mathrm{dS} \mathrm{m}{ }^{-1}$ ). That meaning the morphological properties and yield of quinoa plant will be decreased due to salt stress. Morphological plant adaptations included a reduction in leaf area with a consequent reduction in assimilatory material per unit of plant material and reduction in water use. In conclusion, the highest values in most of the morphological traits were studied when using salinity irrigation water at a rate $4 \mathrm{dS} \mathrm{m}^{-1}$ to irrigate quinoa plant under greenhouse conditions, which proves that the quinoa crop resistant to salinity.

\section{Acknowledgements}

This paper was extracted from research project, which funded by the Deanship of Scientific Research of King Faisal University, Saudi under grant No. 130114. The authors and researchers team therefore acknowledge with 
thanks to Deanship of Scientific Research of King Faisal University.

\section{References}

Ana Maria, C. R., Mariana, R., Mirna, H., Gonzalez, A. J., \& Prado, F. E. (2010). The role of cotyledon metabolism in the establishment of quinoa (Chenopodium quinoa) seedling growing under salinity. Plant Soil, 326, 213-224. http://dx.doi.org/10.1007/s11104-009-9999-8

Bartels, D., \& Sunkar, R. (2005). Drought and salt tolerance in plants. Crit. Rev. Plant Sci., 24, 23-58. http://dx.doi.org/10.1080/07352680590910410

Bhargava, A., Shukla, S., \& Ohri, D. (2003a). Genetic variability and heritability of selected traits during different cuttings of vegetable Chenopodium. Ind. J. Genet. Plant Breed, 63(4), 359-360.

Bhargava, A., Shukla, S., Katiyar, R. S., \& Ohri, D. (2003c). Selection parameters for genetic improvement in Chenopodium grain on sodic soil. J. Appl. Hort, 5(1), 45-48.

Cocozza, C., Pulvento, C., Lavini, A., Riccardi, M., d'Andria, R., \& Tognetti, R. (2013). Effects of increasing salinity stress and decreasing water availability on ecophysiological traits of quinoa (Chenopodium quinoa Willd.) grown in a Mediterranean-type agroecosystem. J Agro Crop Sci, 199, 229-240. http://dx.doi.org/10.1111/jac.12012

Eisa, S., Hussin, S., Geissler, N., \& Koyro, H. W. (2012). Effect of NaCl salinity on water relations, photosynthesis and chemical composition of Quinoa (Chenopodium quinoa Willd.) as a potential cash crop halophyte. Aust $J$ of Crop Sci, 6(2), 357-368.

Flowers, T. J. (2004). Improving crop salt tolerance. J Exp Bot, 55, 307-319. http://dx.doi.org/10.1093/jxb/erh003

Flowers, T. J., \& Colmer, T. D. (2008). Salinity tolerance in halophytes. New Phytol, 179, 945-963. http://dx.doi.org/10.1111/j.1469-8137.2008.02531.x

Garcia, M., Raes, D., Jacobsen, S. E., \& Michel, T. (2007). Agroclimatic contraints for rainfed agriculture in the Bolivian Altiplano. J. Arid Environ, 71, 109-121. http://dx.doi.org/10.1016/j.jaridenv.2007.02.005

Greeway, H., \& Munns, R. (1980). Mechanisms of Salt Tolerance in Nonhalophytes. Ann Rev of Plant Physio., 31, 149-190. http://dx.doi.org/10.1146/annurev.pp.31.060180.001053

Geissler, N., Hussin, S., \& Koyro, H. W. (2009a). Interactive effects of $\mathrm{NaCl}$ salinity, elevated atmospheric CO2 concentration on growth, photosynthesis, water relations and chemical composition of the potential cash crop halophyte Aster tripolium L. Environ Exp Bot, 65, 220-231. http://dx.doi.org/10.1016/j.envexpbot.2008.11.001

Koyro, H. W., \& Eisa, S. S. (2007). Effect of salinity on composition, viability and germination of seeds of Chenopodium quinoa Willd. Plant Soil, 302, 79-90. http://dx.doi.org/10.1007/s11104-007-9457-4

Koyro, H. W., Lieth, H., \& Eisa, S. S. (2008). Salt tolerance of chenopodium quinoa willd., grains of the Andes: Influence of salinity on biomass production, yield, composition of reserves in the seeds, water and solute relations. Tasks for Vegetation Sciences, 43, 133-145. http://dx.doi.org/10.1007/978-1-4020-6720-4_13

Hariadi, Y., Marandon, K., Tian, Y., Jacobsen, S. E., \& Shabala, S. (2011). Ionic and osmotic relations in quinoa (Chenopodium quinoa willd.) plants grown at various salinity levels. $J$ Exp Bot, 62, 185-193. http://dx.doi.org/10.1093/jxb/erq257

Jacobsen, S. E. (2003). The worldwide potential of quinoa (Chenopodium quinoa Willd.). Food Rev Int, 19, 167-177. http://dx.doi.org/10.1081/FRI-120018883

Jacobsen, S. E., Monteros, C., Christiansen, J. L., Bravo, L. A., Corcuera, L. J., \& Mujica, A. (2005). Plant responses of quinoa (Chenopodium quinoa Willd.) to frost at various phonological stages. Eur. J. Agro, 22(2), 131-139. http://dx.doi.org/10.1016/j.eja.2004.01.003

Jacobsen, S. E., Quispe, H., \& Mujica, A. (2001). Quinoa: an alternative crop for saline soils in the Andes. In Scientist and Farmer-Partners in Research for the $21^{\text {st }}$ Century. CIP Program Report 1999-2000 (pp. 403-408).

Malcolm, C. V., Lindley, V. A., O’Leary, J. W., Runciman, H. V., \& Barrett-Lennard, E. G. (2003). Halophyte and glycophyte salt tolerance at germination and the establishment of halophyte shrubs in saline environments. Plant Soil, 253, 171-185. http://dx.doi.org/10.1023/A:1024578002235

Morita, N., Hirata, C., Park, S. H., \& Mitsunaga, T. (2001). Quinoa flour as a new food stuff for improving dough and bread. J Appl Glyco Sci, 48(3), 263-270. http://dx.doi.org/10.5458/jag.48.263 
Munns, R. (2002). Comparative physiology of salt and water stress. Plant, Cell Environ, 25, 239-250. http://dx.doi.org/10.1046/j.0016-8025.2001.00808.x

Munns, R. (2005). Genes and salt tolerance: bringing them together. New Phytol, 167, 645-63. http://dx.doi.org/10.1111/j.1469-8137.2005.01487.x

Munns, R., \& Tester, M. (2008). Mechanisms of salinity tolerance. Annu Rev. Plant Biol, 59, 651-681. http://dx.doi.org/10.1146/annurev.arplant.59.032607.092911

Panuccio, M. R., Jacobsen, S. E., Akhtar, S. S., \& Muscolo, A. (2014). Effect of saline water on seed germination and early seedling growth of the halophyte quinoa. AoB Plants, 19(6), plu047. http://dx.doi.org/10.1093/aobpla/plu047

Page, A. L., Miller, R. H., \& Keeney, D. R. (Eds.). (1982). Methods of Soil Analysis: Part 2, Chemical and Microbiological Properties. Agronomy Series No 9. American Society of Agronomy, Madison, WI.

Pearsall, D. M. (1992). The origins of plant cultivation in South America. In C. W. Cowan \& P. J. Watson (Eds.), The Origins of Agriculture (pp. 173-205). Smithsonian Institute Press, Washington, DC.

Piper, C. S. (1957). Soil and plant analysis. Inter-Science, Inc., New York.

Prakash, D., \& Pal, M. (1998). Chenopodium: seed protein, fractionation and amino acid composition. Int. J. Food Sci. Nutr., 49, 271-275. http://dx.doi.org/10.3109/09637489809089398

Razzaghi, F., Ahmadi, S. H., Adolf, S. H., Jensen, C. R., Jacobsen, S. E., \& Andersen, M. N. (2011a). Water relations and transpiration of quinoa (Chenopodium quinoa Willd.) under salinity and soil drying. J. Agr. Crop Sci, 197, 348-360. http://dx.doi.org/10.1111/j.1439-037X.2011.00473.x

Repo-Carrasco, R., Espinoza, C., \& Jacobsen, S. E. (2003). Nutritional Value and Use of the Andean Crops Quinoa (Chenopodium quinoa) and ka niwa (Chenopodium pallidicaule). Food Rev. Int, 19, 179-189. http://dx.doi.org/10.1081/FRI-120018884

Richards, R. A. (1992). Increasing salinity tolerance of grain crops: is it worthwhile? Plant Soil, 146, 89-98. http://dx.doi.org/10.1007/BF00012000

Rosa, M., Hilal, M., González, J. A., \& Prado, F. E. (2004). Changes in soluble carbohydrates and related enzymes induced by low temperature during early developmental stages of quinoa (Chenopodium quinoa) seedlings. J Plant Physio, 161, 683-689. http://dx.doi.org/10.1078/0176-1617-01257

Ruffino, A. M. C., Rosa, M., Hilal, M., Gonzalez, J. A., \& Prado, F. E. (2010). The role of cotyledon metabolism in the establishment of quinoa (Chenopodium quinoa) seedlings growing under salinity. Plant and Soil, 326, 213-224. http://dx.doi.org/10.1007/s11104-009-9999-8

Tammam, A. A., Alhamd, M. F. A., \& Hemeda, M. M. (2008). Study of salt tolerance in wheat (Triticum aestivum L.) cultivar Banysoif 1. Aust J Crop Sci, 1(3), 115-125.

Tobe, K., Li, X., \& Omasa, K. (2000). Seed germination and radicle growth of a halophyte, Kalidium capsicum (Chenopodiaceae). Ann Bot, 85, 391-396. http://dx.doi.org/10.1006/anbo.1999.1077

United States Salinity Laboratory Staff. (1954). Saline and alkaline soils. Agric. Handbook No. 60 (p. 160). U. S. Dept. Agric., Washington, D. C.

USDA-ARS. (2008). Research databases. Bibliography on salt tolerance. Riverside, CA: US Dep. Agric., Agric. Res. Serv., U.S. Salinity Lab.

Zucconi, F., \& Berttoldi, M. (1978). Compost specifications for the production and characterization of compost from municipal soild wastes. In M. de Bertoldi, P. M. Ferranti, \& P. F. M. L'Hermite (Eds.), Compost: Production quality and Use (pp. 20-29). Elseveir, London.

\section{Copyrights}

Copyright for this article is retained by the author(s), with first publication rights granted to the journal.

This is an open-access article distributed under the terms and conditions of the Creative Commons Attribution license (http://creativecommons.org/licenses/by/3.0/). 